\title{
橋台背面ジオシンセティックス補強盛土の セメント改良によるインテグラルブリッジの安定化
}

相馬亮一 ${ }^{1}$ 、錦織大樹 ${ }^{1}$ 、龍岡文夫 ${ }^{2}$ 、有田貴司 ${ }^{3}$ 、坂井優 ${ }^{3}$ 、田村知宏 ${ }^{3}$ 、 平川大貴 ${ }^{4}$ 、相澤宏幸 ${ }^{5}$

インテグラルブリッジの橋台背面盛土を橋台背面に剛結した多数のジオグリッド層で補強し た新しい橋梁形式である GRS一体橋梁（Geosynthetic-Reinforced Soil Integral bridge）の地震時及 び常時安定性は、盛土が無補強であるインテグラルブリッジと比較して非常に高い。GRS一体 橋梁の地震時崩壊が生じる場合は、橋桁と RC 橋台構造物の慣性力によって生じる盛土上部の 受働破壊が引き金となり、最終的には橋台下端が主働方向に変位し破壞に至る。したがって、 橋台の背面盛土の受働抵抗を増加させると地震時安定性が向上する可能性が高い。本研究では 地震時における GRS 一体橋梁の背面盛土セメント固化の影響を振動台実験により、インテグラ ルブリッジの欠点である気温変動による橋枌の熱膨張収縮が橋台背面のセメント改良盛土に与 える影響を繰返し載荷模型実験により検証した。その結果、背面盛土をセメント改良すること により盛土は常時・地震時共に安定性が向上した。

キーワード：インテグラルブリッジ、セメント改良、振動台実験、水平繰返し載荷

1.はじめに

近年多発する大地震では様々な土木構造物が崩壊し、 復旧に多大な時間と経費を要している。特に鉄道・道 路という線形構造物では、一か所の崩壊がシステム全 体に影響を及ぼして社会的な影響が大きい。したがっ て、レベル II 地震に対し十分な耐震性能を有し、かつ 建設費・維持管理に優れた橋梁形式に対する社会的ニ 一ズが増大している。

筆者らはこのニーズに応える新しい橋梁形式として、 インテグラルブリッジの背面盛土に利用して橋台背面 に定着したジオシンセティックス補強材で盛土を補強 し、その上で支承を取り除いて橋桁と橋台を一体化し た新しい橋梁形式 (Geosynthetic-Reinforced Soil Integral Bridge: GRS-IB) を提案した（図－1） 1)。

筆者らが従来実施した GRS-IB の振動台実験によって、 その地震時破壊モード（図－2）が明らかとなっている。

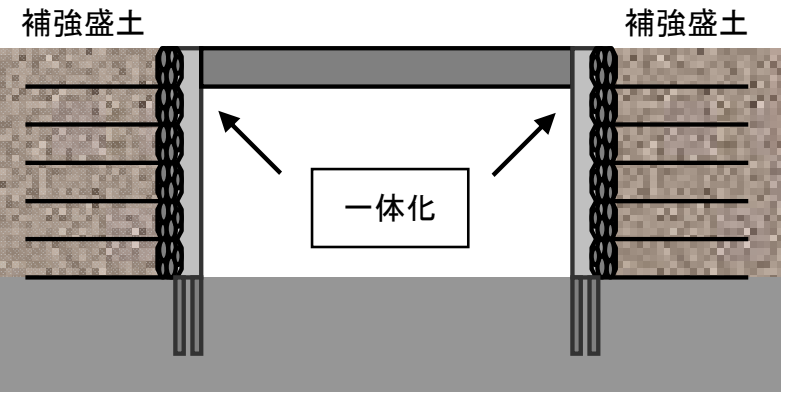

図-1 GRS 一体橋梁

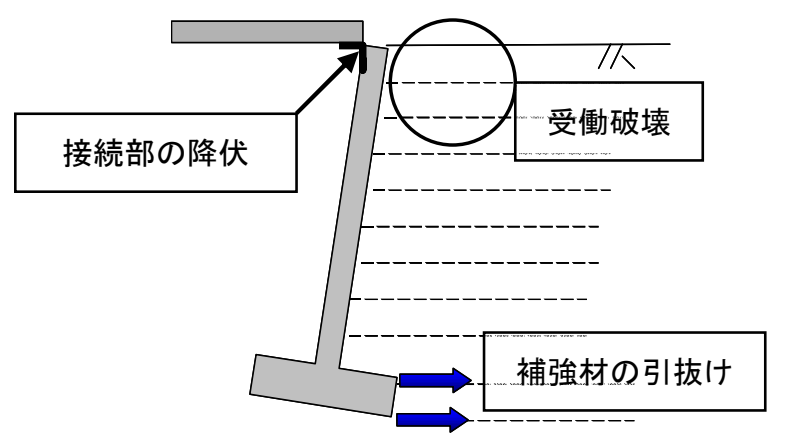

図-2 GRS 一体橋梁の地震時破壊メカニズム

1 IGS 学生会員, 東京理科大学大学院理工学研究科土木工学専攻（广278-8510 千葉県野田市山崎 2641）

2 IGS 正会員, 東京理科大学土木工学科, 教授（同上）

3 非会員, 東京理科大学理工学部土木工学科, (同上)

4 IGS 正会員, 防衛大学校建設環境工学科, 助教（广239-8686横須賀市走水 1-10-20)

5 IGS 正会員，（独）鉄道建設・運輸施設整備支援機構，（長野県長野市大字中御所字岡田 45-1） 
すなわち、(1)橋桁と橋台の慣性力が繰返し盛土上部に 作用して盛土上部が受動破壊し、(2)慣性力に抵抗する 抵抗力の作用位置が下方に低下し、(3)橋桁と橋台の接 続部が降伏を開始し、(4)下部補強材の抵抗力の䘫失に より橋台下部が上端を中心に主働方向に回転変位する ことにより全体的な破壊に至る 2)。したがって地震時破 壊の引き金である(1)が生じることを防ぐ、あるいは遅 らせることで GRS-IB の耐震性能を向上できる可能性が 高い。

一方、インテグラルブリッジは橋桁を支持する可動 支承がないため、気温変化による橋析の熱伸縮によっ て背面盛土に繰返し水平変位が加わる。このため、盛 土が無補強の場合は橋台背後で盛土の沈下や土圧増加 が生じて橋梁構造物としての機能を損なわれる㲊があ る。しかし橋台に結合した多層のジオグリッド補強材 で背面盛土を補強してある GRS-IB では、盛土の残留沈 下は大幅に抑制でき、また土圧増加も抑制されるが仮 に増加しても構造的な問題が生じないことが明らかと なっている3)。

本研究では、想定した実大構造物を $1 / 10$ に縮尺し た GRS-IB 模型の背面盛土にセメント改良域を設け、 その効果を振動台実験によって検証した。また、同様 にセメント改良域を有する GRS-IB 模型を用いて盛土 上部の静的な水平繰返し載荷を行い、季節温度変化に よる橋桁熱伸縮に対する背面盛土のセメント改良の効 果を検討した。

\section{2. 振動台実験}

\section{(1) 実験概要}

図一3 に背面盛土セメント改良をした GRS-IB 模型を 示す。振動台に設置した平面ひずみ土槽（長さ 2,058 $\mathrm{mm} \times$ 奥行き $600 \mathrm{~mm}$ ×高さ $1400 \mathrm{~mm}$ ）の内部に厚さ $35 \mathrm{~cm}$ の支持地盤を作成し、模型をその上に設置した。橋台 模型はジュラルミン製で幅 $45 \mathrm{~mm} \times$ 高さ $450 \mathrm{~mm}$ である剛 なものである。幅 $200 \mathrm{~mm} \times$ 高さ $60 \mathrm{~mm}$ の直接基礎で支持 されていて杭基礎がないため、支持力は実構造物の場 合よりも低い。橋台及び基礎の地盤と盛土との接触面 は、サンドペーパー（\#150）を貼り付け十分に粗にした。

GRS-IB の破壞モードは橋台がその上端を中心とした 主働方向への回転変位であるため、橋析と橋台の接続 部の強度が橋梁の耐震性能を支配する。本実験では、 橋桁と橋台をジュラルミン製 L 型金具（厚さ $3 \mathrm{~mm}$ 、長 さ $200 \mathrm{~mm}$ ) で接続した。この L 型金具は密な豊浦砂の 背面盛土が破壊する前に降伏するように設計されてい

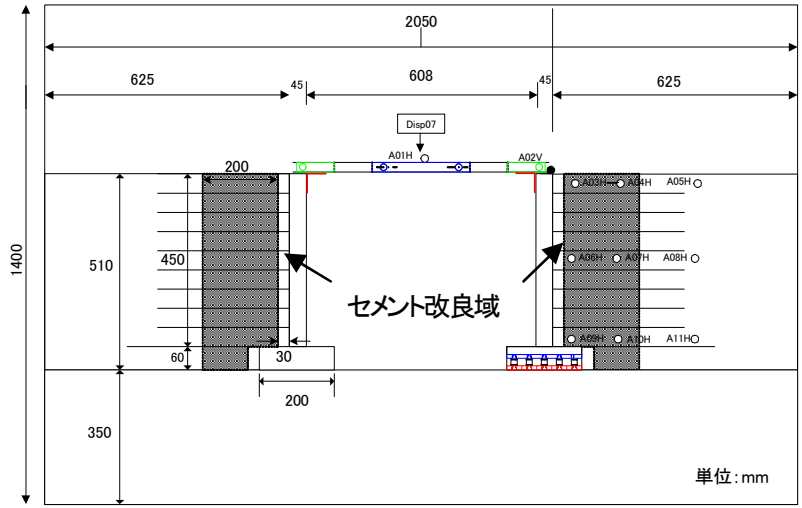

図 - 3 背面盛土をセメント改良した GRS-IB 模型概要

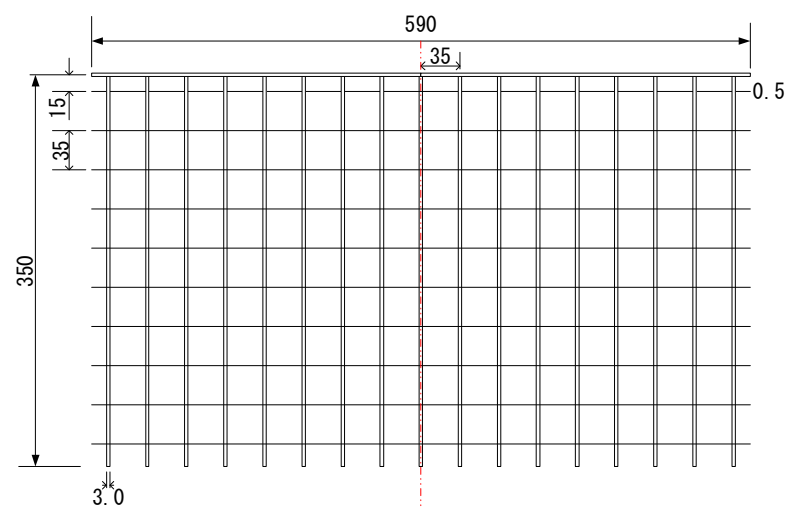

図-4 補強材模型

るため、この点でも実構造物よりも構造的に安定性が 低い 4。また、橋林の中央部に $180 \mathrm{~kg}$ の鍾を載せて、 等価橋桁長が壁高の約 4 倍（約 $2 \mathrm{~m} ）$ となるようにした。 図一－に、模型補強材を示す。リン青銅製であり、表 面はアラルダイト接着剤を用いて豊浦砂を付着させ十 分に粗にした。GRS-IB 模型の橋台背面盛土には片側 10 層の補強材を敷設し、補強材は橋台背面とは厚さ $1 \mathrm{~mm}$ の鉄板を介して M3 ボルトにより 6 点で結合した。気中 での引張り試験の結果、模型補強材と橋台との定着強 度は $1,070 \mathrm{~N} /$ 層であった。

模型の支持地盤および背面盛土は、空気乾燥豊浦砂 を用いて初期相対密度 $D r=90 \%$ となるように空中落下 法により作成した。セメント改良域は愛知県産硅砂 6 号を用いて長さ $200 \mathrm{~mm} \times$ 高さ $510 \mathrm{~mm} \times$ 奥行き $600 \mathrm{~mm}$ とした （図一-3）。今回の実験では、盛土の受働抵抗を増加さ せる目的でセメント改良ブロックを施工しているため、 その施工性を考慮しセメント改良域の背後を鉛直にし た。セメント改良域の形状と大きさの効果は、今後検 討寸る必要がある。セメント改良域と橋台の間には、 実構造物で橋标の温度伸縮を出来るだけ吸収する目的 を持つ緩衝領域を厚さ $30 \mathrm{~mm}$ の未改良硅砂の層によって 設けた。動的荷重はマスに比例して抵抗力は面積 $\times$ 強 
度に比例するため、長さの相似比 $\lambda_{\mathrm{L}}=1 / 10$ の模型の強度 も $\lambda_{\mathrm{L}}$ に比例する必要がある。今回の場合の実現場での 一軸圧縮強度 $q_{u}=2 \mathrm{MPa}$ として、対応寸る $\left(q_{\mathrm{u}}\right)_{\mathrm{m}}=200 \mathrm{kPa}$ が、硅砂の質量に対するセメント配合量は $\mathrm{c} / \mathrm{s}=4 \%$ と した場合 5 日養生時に実現することを、事前に実施し た一軸圧縮試験によって確認した。セメント固化の均 一性を確保するためにセメントペースト量を多くする 目的で、締固め時の含水比は「硅砂の最適含水比 $W_{\mathrm{opt}}=$ $15.6 \% 」+2 \%=17.6$ \%とした。セメント改良部の養生に よる剛性の上昇は、重鍾落下試験（FWD 試験）により確 認した ${ }^{5)}$ 。その結果、セメント改良部と豊浦砂盛土の 剛性を比較すると約 6 倍であった。なお、FWD 試験と室 内三軸圧縮試験で得た経験式によって実際の GRS-IB 模 型のセメント改良盛土部の最大圧縮強度を推定すると、

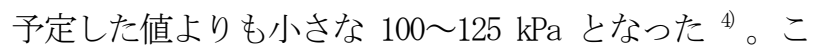
の原因は、セメント改良砂を制作した後、その内部か ら水分が支持地盤内に抜けたため水和反応が不十分に なったためと考えられる。したがって、実構造物より も不利な条件で実験を実施したことになる。

加振は、正弦波 $5 \mathrm{~Hz}$ 、計 20 波を 1 段階とし水平加速 度振幅を 100 gal から開始し 100 gal ずつ増加させるス テップ加振とした。セメント改良ブロックを有する GRS-IB 模型では、セメント改良部を打設後 5 日間養生 してから加振した。

\section{（2）実験結果及び考察}

図－5 に背面盛土をセメント改良しない場合とした場 合の GRS-IB 模型の破壊形状を示す。セメント改良しな い場合は入力加速度 1048 gal（設定值 $1100 \mathrm{gal}$ ）で破壊 したが、セメント改良をした場合は 1136 gal（設定值 1200 gal）の時に橋台がセメント改良部を伴い主働方向 に変位して破壊した。図一6 に、各載荷段階における橋 台背面から $50 \mathrm{~mm}$ 及び $350 \mathrm{~mm}$ の位置での鉛直沈下量 $\delta$ の橋台高さ $\mathrm{H}$ に対する比（残留沈下比）之台加速度の 関係を示す。壁面近傍（橋台から $50 \mathrm{~mm}$ ) では約 900 gal まではセメント改良の有無にかかわらず沈下は無い のに対し、セメント改良した場合は約 $900 \mathrm{gal}$ 付近から やや隆起した。これは長方形のセメント改良ブロック が橋台の回転に伴い傾斜したためと考えられる。壁面 から $350 \mathrm{~mm}$ では、セメント改良が無い場合は約 $800 \mathrm{gal}$ から盛土が隆起した。これは加速度の増加により盛土 に対する橋梁系の慣性力も増加し、盛土が受働破壊を 起こしたためである。これに対して、セメント改良し た場合は振動台加速度が 1136 gal になるまでほとんど 沈下・隆起していない。このことは、セメント改良ブ ロックが盛土の受働破壊を大きく抑制していることを 示している。1136 gal 加振時には盛土が隆起したが、こ れは振動台加速度の増加により橋梁系の慣性力が増加
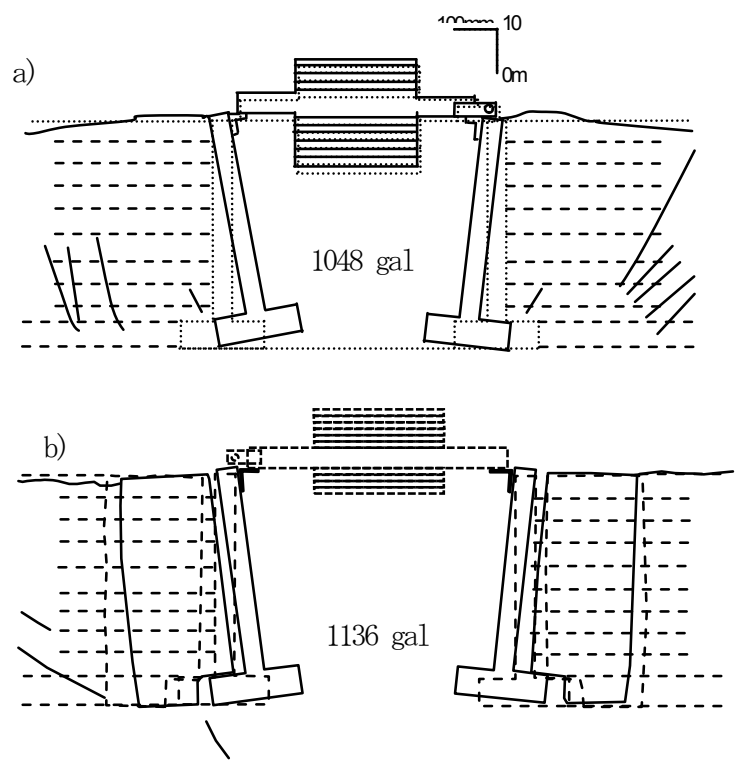

図-5 橋梁模型の破壊形状 a) セメント改良なし b) 背面セメン改良

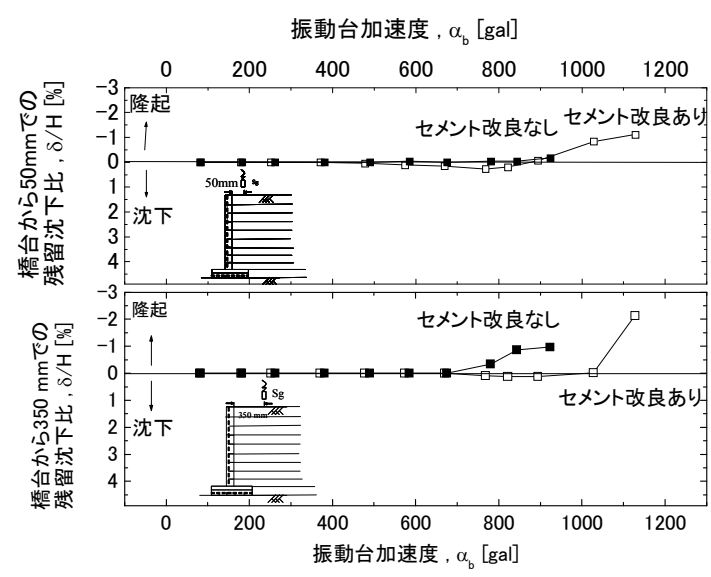

図-6 各位置での沈下比之振動台加速度の関係

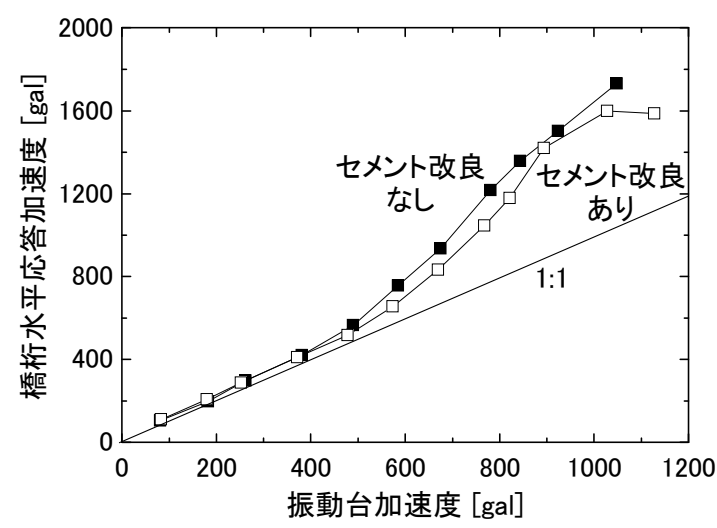

図-7 橋桁の応答加速度之振動台加速度の関係 


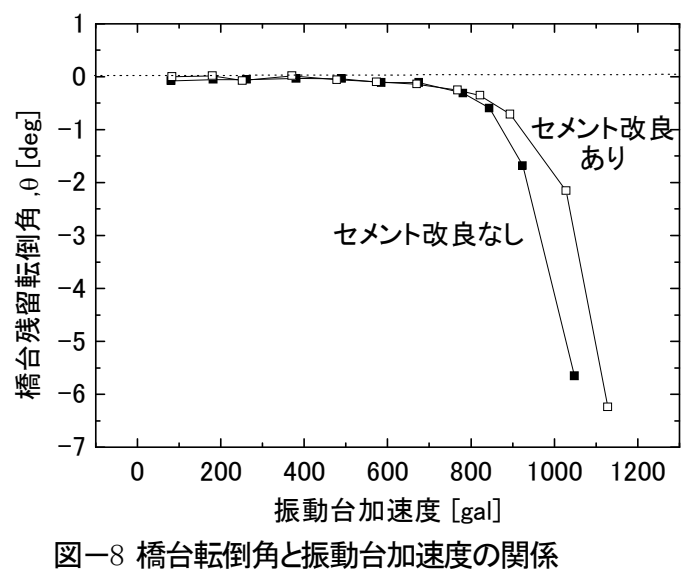

してセメント改良部背後の未改良豊浦砂盛土が受働破 壊したためと考えられる。

図-7 に、橋栴の各載荷段階での 10 波目の橋林の応 答水平加速度と振動台加速度の関係を示寸。600 gal 以 降は、どちらの模型でも橋桁は振動台より加速度応答 值は大きい。これは、橋桁＋橋台の慣性力が繰返し盛 土上部に作用する度に橋台上部が盛土に押し込まれて いることを示している。また、セメント改良した場合 の橋杵応答加速度はセメント改良していない場合より も約 $100 \mathrm{gal}$ 小さい。このことは、セメント改良ブロッ クが橋桁十橋台の押込み荷重に対して有効に抵抗して いることを示している。図-8に、橋台の残留転倒角と 振動台加速度の関係を示寸。転倒角は図-3 に示寸模型 の右側橋台の画像解析から求めた残留回転角度である。 セメント改良ブロックの有無にかかわらず、約 $800 \mathrm{gal}$ で橋台が動き出している。しかし、セメント改良を有 寸る場合の方が安定しており、約 $1000 \mathrm{gal}$ 加振後から 未改良の豊浦砂盛土の受働破壊を原因として大きく橋 台が変位している。図一-9に、橋梁模型が最も盛土の受 働方向に変位した瞬間の土圧の分布と盛土深さの関係

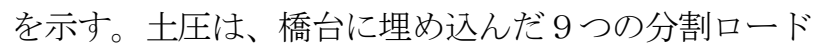
セルによって計測した。セメント改良した場合は、橋 桁+橋台の慣性力に盛土上部が有効に抵抗している。し かし、振動台加速度が 1000 gal を超えると土圧の中心 が著しく低下している。これはセメント改良部が補強 材との境界面で破壞し、それに伴いその背面の未改良 豊浦砂が受働破壞したためである。図一10に $1100 \mathrm{gal}$ 入力時の転倒角の時刻歴を示す。セメント改良した場 合はそれの破壊が開始しても橋梁は脆性的に破壊して いない。この段階では、セメント改良部は補強材によ り橋台と一緒に変位して橋台が厚くなったのと同じよ うな挙動を示寸ためであろう。しかし、1000 gal 以上の 加速度では橋梁が破壊に向かい、転倒角の増加率はセ メント改良をしていない場合とほぼ同じである。した

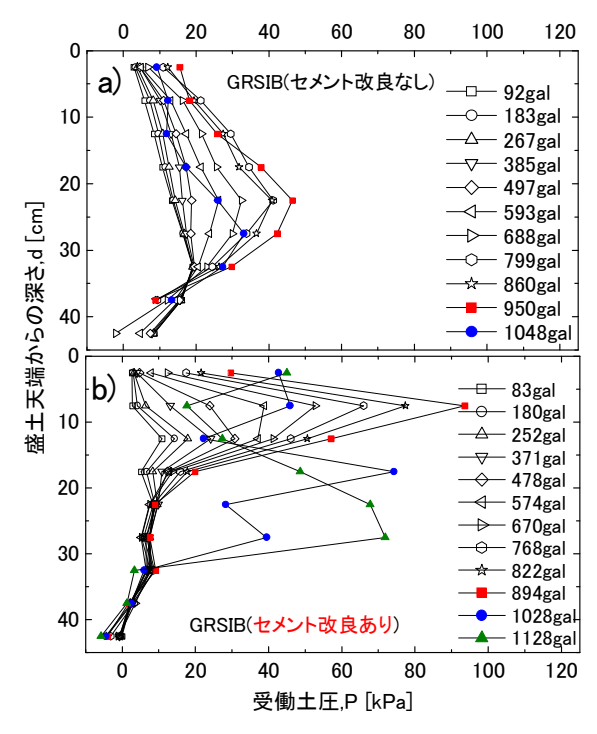

図一9 各載荷段階における深さ方向の土圧分布 a) セメント改良なしb) セメント改良あり

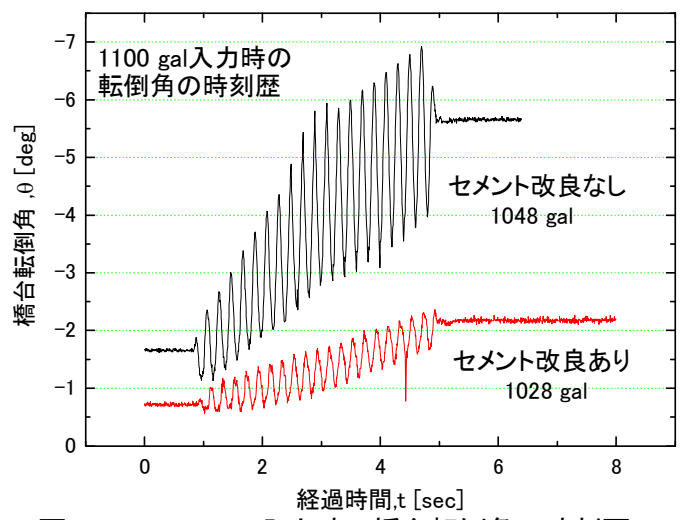

図-10 $1100 \mathrm{gal}$ 入力時の橋台転倒角の時刻歴

がって、この段階ではセメント改良部底面の摩擦によ る抵抗は小さいと考えられる。以上の結果から、背後 の盛土をセメント改良すると GRS-IB の而震性は向上す ることが分かった。しかし、有効なセメント改良域の 強度・大きさ・形を、その施工性・経済性を考慮して 決定するためには、更に研究が必要である。

3. 気温変化による橋桁の熱伸縮を想定した繰り 返し水平載荷試験

\section{（1）実験概要}

図-11 に示す平面ひずみ土槽（長さ $1800 \mathrm{~mm} \times$ 高さ $800 \mathrm{~mm} \times$ 奥行き $400 \mathrm{~mm}$ ) 内に長さ $1,295 \mathrm{~mm} \times$ 高さ $590 \mathrm{~mm}$ ×奥行き $400 \mathrm{~mm}$ の GRS-IB 全体系の片側だけの模型を作 製した。模型橋台は高さ $480 \mathrm{~mm} \times$ 幅 $65 \mathrm{~mm} \times$ 奥行き 390 mm であり、橋台背面には 9 つの分割ロードセルを設置 
し、その面はサンドペーパー（\#150）を張り付けて十 分に粗にした。橋台の下端は $30 \mathrm{~mm}$ の根入れがある直接 基礎であり、自由に回転・水平変位できる。これは、 前述の振動台実験と同じ条件であり、杭基礎がある実 構造物よりも安定性が低い条件である。背面盛土（未 改良部）および支持地盤は豊浦砂を用いて、相対密度 $D r=90$ \%となるように木槌を用いて突き固め法により作 成した。セメント改良部の使用材料および作成方法は 振動台実験と同じである（2，振動台実験を参照）。 図一 12 及び表一 1 に示すように、使用した補強材はポリ エステル製で表面をポリ塩化ビニルでコーティングし たもので、現場で使用されているものからリブとスト ランドを半分に間引いて面内配置密度と強度を半分に してある。本実験では補強材の伸縮の影響を考慮し、 高分子補強材を用いた。補強材は $5 \mathrm{~cm}$ ごとに全部で 8 層 敷設し橋台背面に M3 ボルト 4 本を用いて定着した。繰 返し水平載荷は、橋台の前面で上端から $11.5 \mathrm{~cm}$ の位置 で Universal Joint とアームを介して結合したギヤ式変 位制御載荷装置を用いて行った。セメント改良した場 合では、セメント改良ブロック施工後養生 5 日目で載 荷を開始した。橋台上端での繰返し変位は主働方向に だけ与えて振幅 D は $3 \mathrm{~mm}$ で一定とした。この振幅 D は、 想定している橋林長 $\mathrm{L}=$ 約 $100 \mathrm{~m}$ の気温の季節変動に伴 う橋林の熱伸縮量を模型の寸法に直した值に対応して いる。壁高に対する転倒量 D/H は、0.625％（壁高 $\mathrm{H}=480$ $\mathrm{mm}$ ) となる。補強盛土に対し繰返し水平変位を主働領域 のみに与えた場合と、主働・受働領域に繰返し水平変 位を与えた場合の変位モードの差が沈下特性・土圧特 性に与える影響は小さいことが明らかとなっている ${ }^{3)}$ 。 図 - 13 に四つの実験ケースを示す。すなわち、セメン 卜改良ブロックの有無、セメント改良域の大きさの影 響を検討した。載荷は、模型が崩壊するか繰返し載荷 回数が 200 になると終了した。

\section{（2）実験結果および考察}

図－14 に各ケースの実験終了時の様子を示す。盛土 が無補強であるインテグラルブリッジで橋台下端が地 盤に直接支持されている場合では、橋台の繰返し変位 によりその背後の盛土が大きく破壞している（相澤ら、 2008）。しかし、橋台背面に定着した多層のジオグリッ ドで盛土を補強したケース(1)では、橋梁の安定性は大き く向上する ${ }^{6}$ 。本研究で新たに行ったジオグリッドによ る補強と盛土のセメント固化を併用したケース(2)、(3) では、いずも盛土に大きな沈下・変位は生じなかった。

a) 補強盛土を全高さセメント改良したケース(2)

このケースでは、セメント改良部のみならずその背 後の未改良豊浦砂盛土にも沈下が殆じ生じなかった

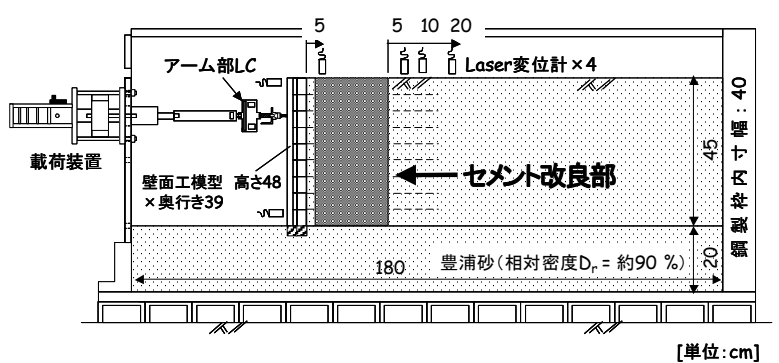

図-11 水平繰返し載荷装置の概要

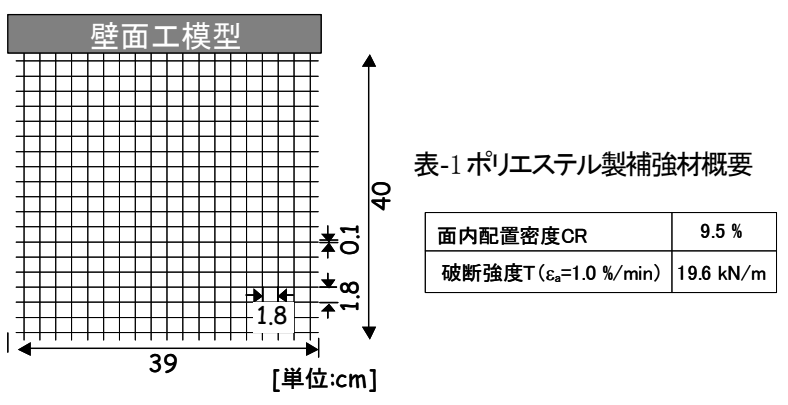

図ー12 ポリエステル製補強材概要

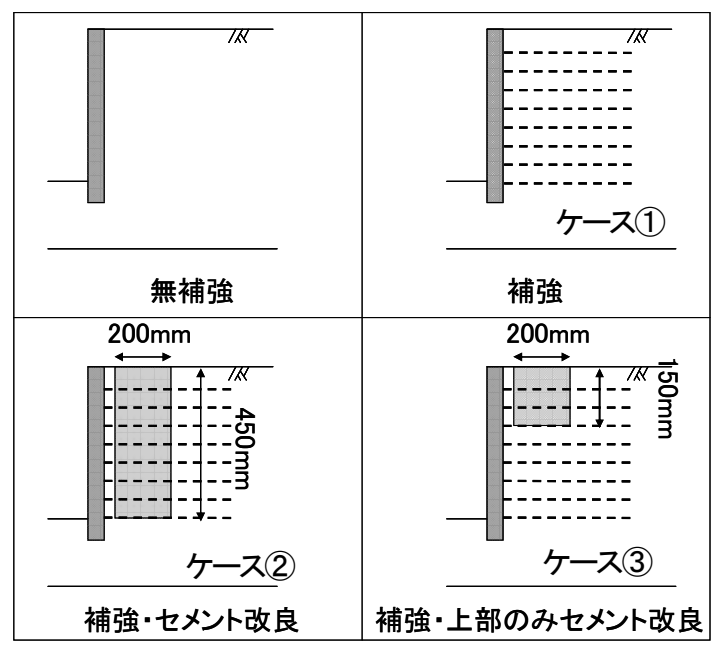

図ー13 実験パターン
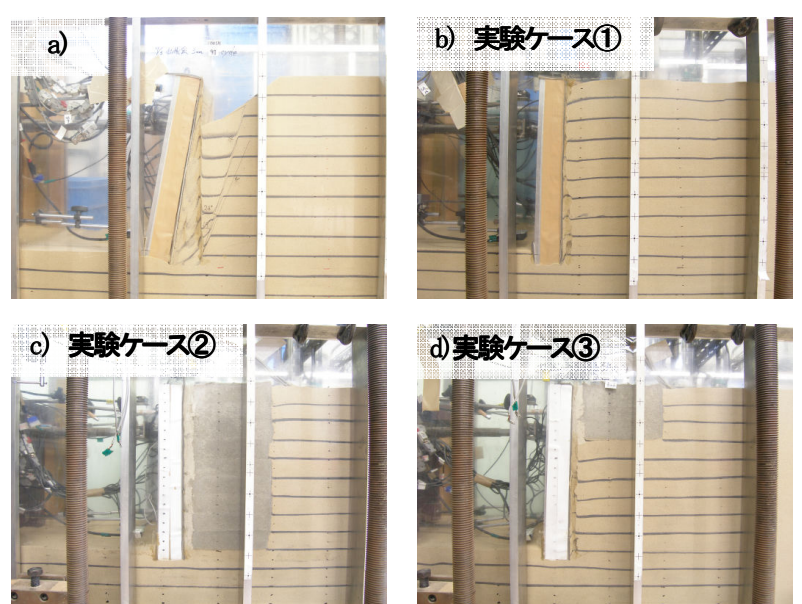

図-14 実験終了時の様子 a) 無補強、90 cycles b) 補強 200cycles c) 補強·セメン改良 200 cycles d) 補強·上部のみセメント改良 200 cycles 


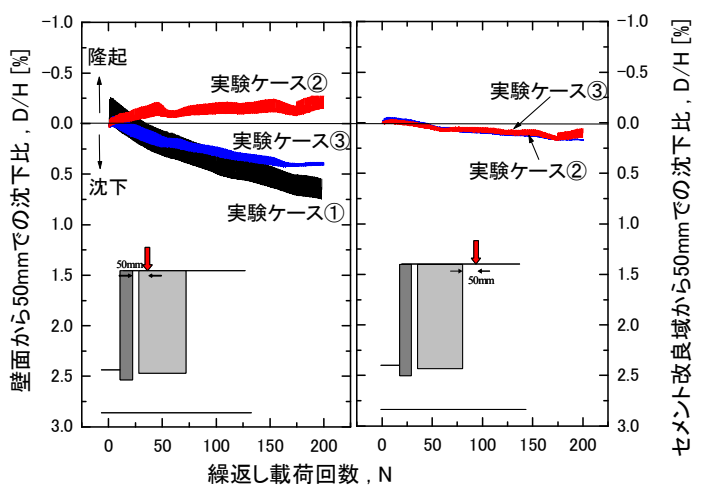

図-15 盛土天端の沈下比と繰返し載荷回数の関係

(図－15）。これは、セメント改良ブロックの背面での 水平変位量は橋台の繰返し水平変位量よりも小さい事 を示している。これは、セメント改良部と橋台の間に 配置した薄い未改良砂層が緩衝領域となり橋台の水平 変位を吸収しているためと思われる。図一16 に、土圧 係数 $\mathrm{K}=2 \mathrm{Q} /\left(\mathrm{\gamma} \mathrm{H}^{2}\right)$ と繰返し載荷回数の関係を示寸。Q は橋 台単位幅に作用寸る総土圧、 $\gamma$ は盛土の単位体積重量、 $\mathrm{H}$ は壁高である。橋台背後の補強盛土を全高さセメント 改良したケース(2)での土圧係数 K の各繰返し載荷での ピーク值は、補強盛土をセメント改良しないケース (1) と比較してやや小さくなっている。これは、前述のよ うにセメント改良域の背後の未改良盛土に生じた繰返 し水平変位が小さくなっているため、主働崩壊による 沈下が減少するとともに受働土圧の増加が抑制された ためと考えられる。これに対応して、橋台下端の主働 方向への変位も大きく軽減されている（図一18）。図一 17 に、各載荷段階で橋台が受働方向に押し込まれた瞬 間の土圧の深さ方向の分布を示す。補強盛土がセメン 卜改良されていないケース(1)では、載荷回数が増加す るとともに橋台中心高さ付近での土圧が大きく増加し ている。これは、橋台背面に結合した補強材を盛土内 に敷設しているが、図一15 に示寸ように繰返し変位に 伴い橋台背後の無補強盛土内に主動崩壊がわずかに生 じて土塊がすべり落下して沈下が生じ、それに対応し て受働土圧メカニズムが発揮されていること（すなわ ち、土圧の dual ratchet 現象 ${ }^{7)}$ が生じたこと）が原因 である。一方、橋台全高さで補強盛土をセメント改良 したケース(2)では、受衝土圧は盛土上部で最も大きい。 GRS-IB の破壊モードは図-5 に示寸ように橋台上部を中 心とした橋台下部の主働方向への回転変位であるため、 土圧の作用中心が盛土上部に維持されていることは、 橋台の主働方向の回転モーメントが増加していないこ とを示している。これは、ケース(2)では橋台下端の杭 基礎等の必要度が低くなっていることを示している。

また、橋台の水平繰返し載荷試験における受働土圧

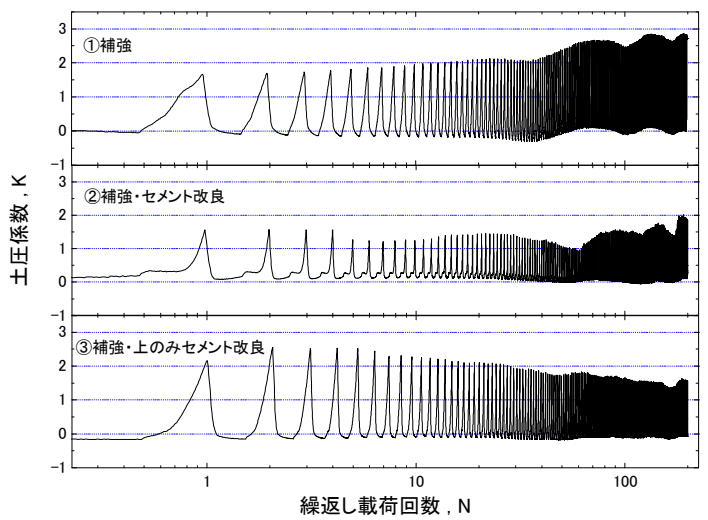

図-16 水平土圧係数と繰返し載荷回数の関係
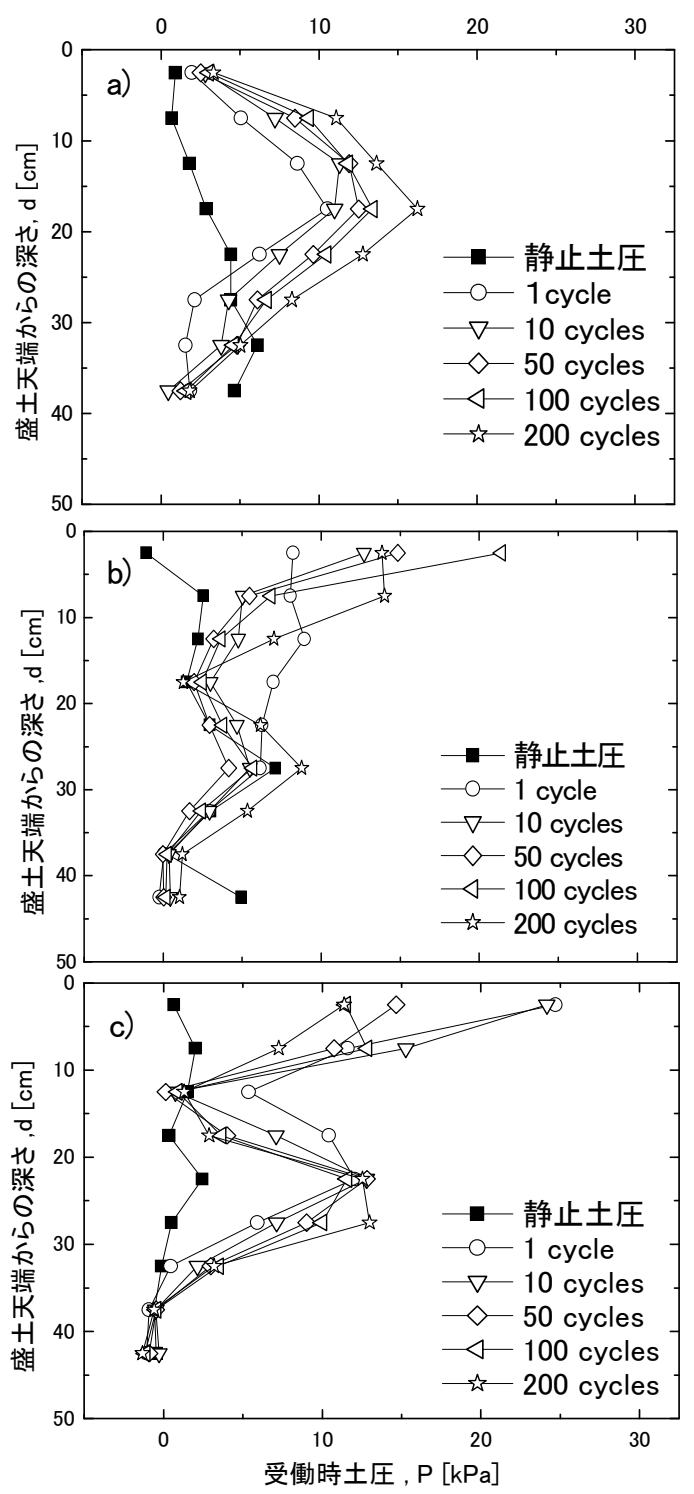

図一17 各載荷段階における盛土深さと土圧分布の関係

a）補強（ケース(1)） b）補強・セメント改良（ケース(2)

c）補強・上部のみセメント改良(3) 
分布 (図-17b) は、振動台実験での受働土圧分布（図 -9b）と傾向が似ている。このことは、両者の実験での 橋台+盛土の変位・変形メカニズムは類似であることを 示している。

b）補強盛士の上部のみをセメント改良をしたケース(3)

図-16 から、ケース(3)の土圧係数 K は繰返し載荷初 期に大きな值を示している。これは、図一17c から分か るように盛土上部のセメント改良域の受働土圧が非常 に大きくなったためである。しかし、その後は繰返し 載荷回数の増加とともに減少傾向を示している。これ は、図-17c から分かるように盛土上部のセメント改良 域の受働土圧が徐々に減少しているためである。この 傾向は、盛土上部しかセメント改良していないため、 そのセメント改良域の安定性は全壁高さに亘るセメン 卜改良域（ケース(2)）よりも低いためであろう。また、 図一17c から、ケース(3)でもセメント改良をしていない ケース(1)と同様に、壁面中心高さで大きな受働土圧を 示している。これは、橋台の水平繰返し載荷に伴って 下部の未改良盛土の内部でケース (1) と同様に Dual ratchet 現象 ${ }^{7)}$ (主動崩壊と受働土圧増加メカニズムの 発達）が生じたためであろう。

図-15 に、橋台背後とセメント改良部背後での沈下 比と繰返し載荷回数の関係を示す。ケース(3)で盛土上 部だけセメント改良した場合、セメント改良部背後の 未改良盛土の沈下はほとんど発生していないが、セメ ント改良部ブロック自身は盛土セメント改良していな いケース(1)と同様に、壁高に対し約 $0.5 \%$ \%やや大きな 沈下が生じている。これはセメント改良部下方の未改 良豊浦砂が鉛直方向に圧縮したためである。これに対 応して、橋台下端がケース(1) と同様に主働方向に変位 している (図 - 18)。以上のことから、盛土の上部の補 強材 3 層分の厚さの盛土だけをセメント改良を施した 場合は、気温変動に伴う橋桁熱伸縮の影響を十分に軽 減できない可能性があることが分かった。

\section{4.まとめ}

橋台背面の盛土をセメント改良した GRS-IB の振動台 実験及び気温変動による橋台上部の水平繰返し変位を 模擬した載荷試験により、以下の知見が得られた。

1）振動台実験において、背面盛土を橋台全高さに亘っ てセメント改良することによって、橋台下端の主働 変位が開始する直後は勒性的な挙動を示した。これ は橋桁十橋台の慣性力に対してセメント改良盛土が その上部で有効に抵抗したためである。このことに

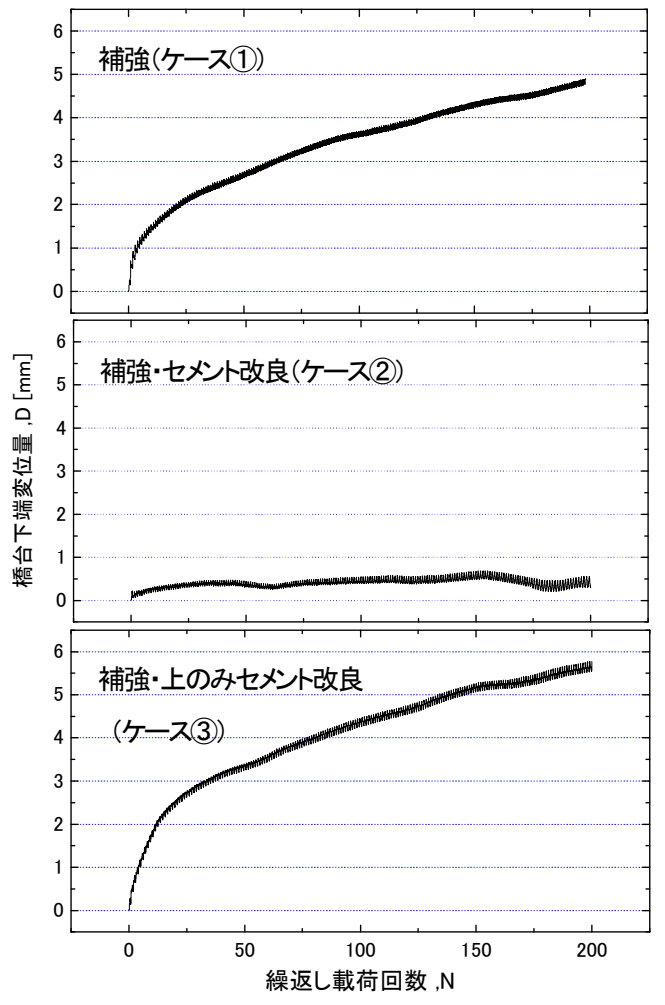

図-18 橋台下端の主働変位量と繰返し回数の関係

より橋台の回転によるその下部の主働変位が抑制さ れ、GRS-IB の而震性能が増加した。

2）橋台上部の水平繰返し載荷試験において、橋台背面 で全高さに亘って盛土をセメント改良した場合、橋 台の水平繰返し変位に対しても受働時に盛土上部が 有効に抵抗した。これにより橋台下端を主働方向に 変位させるモーメントが減少することから、基礎等 を簡略化できるようになる。また、橋台の水平繰返 し変位は橋台とセメント改良盛土の間の緩衝領域に 大きく吸収されるため、セメント改良盛土とその背 面の未改良盛土の残留変位と土压増加は大幅に軽減 した。

3）橋台上部の水平繰返し載荷試験において、橋台背面 の盛土上部（壁高の 1/3）だけをセメント改良した 場合は、橋台の水平繰返し載荷に対寸る安定性は向 上しなかった。これはセメント改良部下方の未改良 部が圧縮したためである。

参考文献

1）平川大貴、龍岡文夫 : 補強土を利用したインテグ ラル橋梁、基礎工、vol. 36、No. 1、pp. 54-57、 2008

2）錦織大樹、笹田泰雄、野尻峯広、相澤宏幸、龍岡 
文夫、平川大貴、渡辺健治、舘山勝、第 3 回地盤 工学会関東支部発表講演集 pp122-126、2006 総合 土木研究所、龍岡文夫監修、新しい補強土擁壁の すべて - 盛土から地山まで -

3）平川大貴、相澤宏幸、錦織大樹、相馬亮一、園田 陽介、龍岡文夫、GRS 一体橋梁の気温変動を想定 した水平繰返し載荷時の変形特性、ジオシンセテ イックス論文集第 22 巻、pp83-90、2007

4）相澤宏幸、盛土のジオシンセティックス補強によ る一体橋梁の安定性向上、東京理科大学修士論文、 2008

5）増田直哉、関根和弘、龍岡文夫、平川大貴、川崎
廣貴、FWD 試験と平板載荷試験の砂地盤の剛性と その関連、第 42 回地盤工学研究発表論文集、 pp. 1151-1152、2007

6）相澤宏幸、錦織大樹、平川大貴、相馬亮一、園田 陽介、龍岡文夫、一体橋梁背後盛土での補強材の 壁面工定着の重要性、ジオシンセティックス論文 集第 22 巻、pp77-82、2007

7）龍岡文夫、平川大貴、相澤宏幸、錦織大樹、相馬 亮一、園田陽介、繰返し水平載荷による盛土の沈 下・土圧増加とジオテキスタイル補強による解決、 ジオシンセティックス論文集第 22 巻、pp69-76、 2007

\title{
Cement-stabilization of geosynthetic-reinforced backfill for integral bridge
}

\section{Ryoichi SOMA, Hiroki NISHIKIORI, Fumio TATSUOKA, Takashi ARITA, Suguru SAKAI, Tomohiro TAMURA, Daiki HIRAKAWA, Hiroyuki AIZAWA,}

\begin{abstract}
Geosynthetic-Reinforced Soil Integral Bridge (GRS-IB) consists of an integral bridge comprising a girder unified to a pair of abutment and the backfill reinforced with geosynthetic-reinforcement layers connected to the back of the facing. It is shown that, cement-mixing the backfill zone immediately behind the abutment, GRS-IB becomes more stable against seismic load as well as cyclic displacements at the top of the abutment due to seasonal thermal deformation of the girder. Failure of GRS-IB is triggered by passive failure at the top of backfill, which results into a pushing out of the bottom of the abutment. It is effective for an increase in the stability of GRS-IB against both seismic and static loading to increase the passive resistance by cement-mixing a relevant zone of the backfill. The above was validated by performing a series of shaking table tests and static cyclic lateral loading tests on scaled models of GRS-IB.
\end{abstract}

